\title{
Miscellanea
}

\section{List of Completed Master Dissertation}

Acharya, Murari. Socio-Economic Impact of Community Forestry Program: A Case Study of Kaski Development Sector 9. MBA diss. 2057.

Adhikari, Durga. Sales Planning on Non-Manufacturing Public Enterprises in Nepal: A Case Study of Nepal Oil Corporation, MBS diss. 2063.

Adhikari, Indu. Dividend Policy of Finance Companies in Nepal, MBS diss. 2063

Adhikari, Jhalak Ram. Profit Planning in Public Utilities Enterprises of Nepal: A Case Study of Nepal Electricity Authority. MBA diss. 2059.

Adhikari, Liladhar. The Effects of Sales Promotion on Brand Choice (with Special Reference to Automobiles. MBA diss. 2059.

Adhikari, Mitra Lal. A Study on Financial Performance of Rural Based Saving and Credit Cooperative Organization: A Case Study of Janhit Saving and Credit Society, Lamachaor, Kaski. MBS diss. 2060.

Adhikari, Thakur Prasad. A Study on Municipal Financing in Nepal: A Case Study of Pokhara Sub-Metropolitan City. MBA diss. 2060.

Adhikari, Vijaya Laxmi. A Study on Profit Planning and Control A Case Study of Diary Development Corporation. MBA diss.2059.

Adhikari, Youba Raj. A Study of Cost Control and Planning in Public Utility Enterprises of Nepal: A Case Study of Nepal Telecommunication Corporation. MBA diss. 2059.

Ale, Padam Bahadur. Service Management in Nepal Telecommunication Corporation. MBS diss. 2062.

Aryal, Salig Ram. Value Added Tax in Nepal: Past and Present, MBS diss. 2063

B.K, Prem Lal. A Comparative Analysis of Financial Performance Analysis of Standard Chartered Bank Ltd. and Nepal SBI Bank Ltd., MBS diss. 2062.

Baral, Buddhi Raj. Comparative Study on the Financial Performance of Nepal Bank Ltd. and Grindlays Bank Ltd. MBA diss. 2056.

Baral, Naranath. A Case Study of PDDD, Milk Product Marketing in Pokhara. MBA diss. 2059.

Baral, Puspa Raj. Inventory Management: A Case Study of Gandaki Noodle (PVT) Ltd. MBA diss. 2051

Basnet, Janak Bdr. A Study of Lumbini Sugar Factory. MBA diss. 2053.

Bastola, Babu Ram. A Study of Profit Planning and Control of Manufacturing Public Enterprises in Nepal: A Case Study of Birgunja Sugar Factory Ltd. MBA diss. 2058.

Bastola, Tika Ram. Loan Disbursement and Repayment Pattern of Agricultural Development Bank of Nepal. MBS diss. 2060.

Basyal, Tej Prasad. A Study on Marketing of Mobile Telephone Service in Nepal (with Special Reference to Kathmandu Valley. MBA diss. 2057.

Bhandari, Krishna Ram. Financial Performance Analysis of Himalayan Bank Ltd. in the Framework of CAMEL. MBS diss.

Bhandari, Krishna Ram. Financial Performance Analysis of Himalayan Bank Limited in the Freamework of CAMEL, MBS diss. 2062. 
Bhandari, Narayan Prasad. Working Capital Management in Nepalese Manufacturing Enterprises: A Case Study on of Hulas Steel Industries Pvt. Ltd., MBS diss. 2063.

Bhujel, Krishna Bdr. A Study on Market Position of Rara Brand Noodles in Pokhara. MBS duss. 2061.

Bogati, Tul Bdr. A Study on Poultry Farming in Pokhara Sub-Metropolitan City. MBA diss. 2055.

Bohara, Yaman Singh. A Financial Analysis of Tansen Municipality, MBA diss. 2060.

Budhathoki, Keshav. Financial Analysis and Forecasting of Pokhara Sub-Municipal Corporation. MBA diss.2059.

Chanda, Digendra. Financial Performance Analysis of NABIL Bank Limited in the Framework of CAMELS, MBS diss. 2063.

Dhakal, Rabi Mohan. A Study on Resource Mobilization by Commercial Bank with Reference to Nepal Bank Ltd. MBA diss. 2056.

Dhungana, Sunita. Rural Urban Partnership Program: A Case Study of Pokhara Sub-Municipal Corporation. MBA diss. 2059.

G.C., Surya Bahadur. Dividend Policy of Nepalese Corporate Firms An Analysis of Trend and Determinants. MBS diss. 2061.

Gautam, Lekh Nath. Position of Receivable Management of Listed Manufacturing Companies in Nepal, MBS diss. 2063.

Gautam, Rajendra. A Comparative Study of Biscuits Industries at Pokhara Sub-Metropolis. MBA diss. 2057.

Gewali, Shrijan. A Case Study on the Micro-Credit Project for Women in Pokhara. MBA diss. 2056.

Ghimire, Kiran Raj. Role of Nongovernmental Organization in Tourism Promotion in Pokhara: A Case Study of Pokhara Sub-Metropolitan City. MBA diss. 2060.

Ghimire, Madhav Raj. A Study on Financial Products of Financial Institutions in Pokhara. MBA diss. 2060.

Ghimire, Narayan. Micro Credit Program for Women: A Case Study of Kahun VDC in Kaski District. MBS diss. 2062.

Ghimire, Rabindra. Role of Pokhara Industrial Estate in Employment Generation. MBA diss. 2058.

Ghimire, Ram Chandra. Bricks Industries in Nepal. MBA diss. 2057.

Gurung, Ash Bahadur. Financial Sustainability of Rural Water and Sanitation Program Phase III: The Gurkha Welfare Scheme, MBS diss. 2062.

Gurung, Dev Singh. Planning and Controlling of Investment in Financial Institutions of Nepal: A Case Study of Pokhara Finance Company Limited. MBS diss. 2062.

Gurung, Dhan Prasad. A Case Study on Financial Services of Financial Institutions in Pokhara. MBA diss. 2061.

Gurung, Jash Bdr. Share Price Behavior of Listed Companies in Nepal. MBA diss. 2056.

Gurung, Laxmi. Revenue Planning in Manufacturing Enterprises: A Case Study of Royal Drugs Limited, MBS diss. 2062.

Gurung, Rudra Jung. Non-interest Income and Operating Efficiency of Commercial Banks in Nepal, MBS diss. 2063. 
Gurung, Shusma. Financial Implication of Proper Management of Reusable/Recyclable Waste: A Case Study of Pokhara Sub-Municipal Corporation. MBA diss. 2060.

K.C, Ram Bahadur. A Study on the Investment Policy of Nabil Bank Ltd. MBS diss. 2061.

K.C. Hikmat. The Financial Performance of Lumbini Sugar Mills Ltd. MBA diss. 2054.

K.C. Krishna Bdr. A Study on Dhikuti Associations in Pokhara Sub-metropolis. 2057.

K.C., Kesh Bdr. A Study on the Performance of Agriculture Inputs Corporation. MBA diss. 2055.

Karki, Deepak Bahadur. Risk and Return Analysis of Listed Companies, MBS diss. 2062.

Karki, Dependra. A Study on Investment Policy of Nepal SBI Bank Ltd. MBS diss. 2062.

Karki, Shambhu. Opinion Survey on the Proposed Waste Management Service Charges of Pokhara Sub-Municipal Corporation. MBA diss. 2058.

Lamichhane, Babu Ram. Employment Generation and Employees Empowerment of Cottage and Small Scale Industries in Nepal: A Case Study of Pokhara Sub-Metropolis Area. MBA diss. 2056.

Lamichhane, Bijaya Laxmi. Risk and Return Analysis of Listed Commercial Banks in Nepal, MBS diss. 2063.

Lamsal, Toya Nath. Financial Performance Analysis of Nepalese Cooperatives with Special Reference to District Cooperative Association Ltd. (Kaski district). MBA diss. 2057.

Ligal, Somat. Shareholders' Perception on Dividend Policy of Pokhara Finance Company Limited. MBS diss. 2062.

Magar, Surya Bdr. The Impact of Human Resource Development Strategy on Organizational Productivity: A Case Study of UMN/RDC. MBA diss. 2060.

Manandhar, Suresh Kumar. A Study on the Financial Impact of Child Labor Project's Micro Credit Program on Women in Kaski District, MBS diss. 2063.

Manandhar, Tara. The Enterprise Tax: A Case Study of Pokhara Sub-Municipal Corporation. MBA diss. 2057.

Neupane, Amar Prasad. Buying Behavior of Foreigners in Pokhara: A Study on Household Furniture. MBA diss. 2058.

Neupane, Raju Raman. Mobilization of Female Community Health Volunteers: A Case Study of DPHO-Kaski. MBA diss. 2061.

Neupane, Rudra Prasad. A Study on Revenue Collection Through VAT in Nepal with Reference to Pokhara, MBS diss. 2062.

Ojha, Nirajan Raj. Microfinance in Practice: Loan Recovery Approach to the Performance Assessment of Micro-credit Project for Woman in Pokhara. MBA diss. 2059.

Padhyaya, Megh Nath. Vegetable Production and Marketing in Pokhara Sub-Metropolis. MBA diss. 2058.

Palikhe, Amin. Prospect and Problems of Tourism in Pokhara. MBS diss. 2061.

Pandey, Basanat Raj. A Study on Substantive Plan of Furniture Industries in Pokhara Submetropolitan City Area, MBS diss. 2062.

Parajuli, Basanta Raj. A Study on Personnel Administration in Non-governmental Organization: A Case Study of the International Nepal Fellowship Pokhara. MBA diss. 2058. 
Parajuli, Gangadhar. A Study on Effectiveness of Managerial Budgeting in Annapurna Finance Co. Ltd., MBA diss., 2058.

Parajuli, Krishna Raj. Motive Factors Behind Buyer's Attitudes Towards Bargaining During the Shopping Period at Fancy Shop. MBA diss. 2051

Parajuli, Ram Raj. A Study on Working Capital Management of Nepal Lever Limited. MBA diss. 2058.

Paudel, Bam Dev. Managerial Budgeting in Finance Companies: A Case Study of Pokhara Finance Limited, Pokhara, MBS diss. 2063

Paudel, Bharat Raj. Dividend Policy of Commercial Bank in Nepal. MBS diss. 2060.

Paudel, Bodh Raj. A Study on Working Capital Management of Gandaki Noodle (Pvt) Ltd. MBA diss. 2056.

Paudel, Puspa Raj. Financial Performance of Annapurna Finance Co. Ltd. With Reference to Working Capital Management. MBA diss. 2057.

Paudel, Rajendra Prasad. Small Farmer Development Project in Parbat: A Case Study of Nanglibang VDC, MBS diss. 2062.

Paudel, Ram Chandra. A Study on Working Capital Management of Gorkhakali Rubber Udhyog Ltd. , MBA diss. 2059.

Paudel, Resham Lal. Capital Market and Share Price Behavior in Nepal. MBS diss. 2061.

Paudel, Sheskanta. Loan Effectiveness of Agricultural Development Bank in Nepal. MBS diss. 2060.

Paudel, Sita Devi. Corporate Tax and Industrial Growth in Nepal. MBA diss. 2058.

Paudel, Surendra Raj. A Study of Sales Planning on Diary Development Project in Nepal: A Case Study on Diary Development Project, Pokhara. MBS diss. 2060.

Pokharel, Bishnu Prasad. Small Farmers Development Project: A Case Study of Ghachouwk VDC. MBA diss. 2055.

Pokharel, Khag Prasad. A Study on Profit Planning and Control in Lumbini Sugar Mills Ltd. MBA diss. 2053.

Pradhanang, Sunita. Financial Analysis of Dhangadi Municipality. MBA diss. 2058.

Pulami, Khem Bahadur. Performance Analysis of Prithivi Narayan Campus, Pokhara. MBA diss. 2061.

Pun, Bhim Raj. A Study of Planning and Controlling of Overhead Cost: A Case Study of Pokhara Dairy Development Project, MBS diss. 2062.

Ramesh, Sigdel. A Study on Income Tax Management in Nepal with Reference to Pokhara Valley. MBS diss. 2062.

Rana, Om Bdr. A Case Study on Profit Planning of Himal Cement Company. MBA diss. 2058.

Rijal, Umesh Raj. Diagnosis of Financial Health of Himalayan General Insurance Company Limited in the Framework of IDRA, MBS diss. 2063.

Saiju, Manoj Kumar. A Study on of Investment Policy of Paschimanchal Grameen Bikas Bank, MBS diss. 2063.

Sapkota, Pitambar. A Study on Investment Portfolio of Annapurna Finance Co. Ltd. MBA diss. 2056.

Shakya, Dinesh Raj. Financial Analysis of Joint Venture Bank in Nepal. MBA diss. 2052.

Sharma Pathak, Nanda. A Study on Working Capital Management of Gandaki Brick Factory Ltd. MBA diss. 2059. 
Sharma, Aradhana. A Comparative Study on Financial Analysis of Nepal Lube Oil Ltd. Before and After Privatization. MBA diss. 2060.

Sharma, Devi Lal. Value Added Tax (VAT): Issues and Prospects in Nepal. MBS diss. 2060.

Sharma, Hari Prasad. Personnel Management in Armed Police Force of Nepal. MBA diss. 2060.

Sharma, Prem Prasd. A Case Study on Finance Companies of Nepal. MBA diss. 2061.

Sharma, Resham Raj. Analysis of Capital Structure of Selected Commercial Banks in Nepal. MBS diss. 2062.

Sharma, Shiva Hari. Effects of Sales on Perception of Brand Equity. MBA diss. 2060.

Shrestha, Kishor. Value Added Tax in Nepal: A Case Study of Pokhara Valley. MBS diss. 2062.

Shrestha, Rabindra. Dividend Policy of Insurance Companies in Nepal, MBS diss. 2063

Shrestha, Sanam. A Study on Working Capital Management of Arundaya Metal Industries, Pokhara, MBS diss. 2062.

Shrestha, Shelina. A Study on Investment Portfolio of Pokhara Finance Limited, MBS diss. 2063.

Shrestha, Surendra. A Study on Capacity Utilization and Profitability of Pokhara MiniMicro Buses, Pokha, MBS diss. 2063.

Shrestha, Surya Kumar. Daily Stock Price Behavior of Commercial Banks in Nepal, MBS diss. 2063.

Sigdel, Anuj. Financial Analysis of Local Government: A Case Study of Lamjung District Development Committee. MBS diss. 2062.

Subedi, Madan. Local Government Financial Management: A Case Study of Kaski District Development Committee. MBS diss. 2062.

Subedi, Tika Ram. A Study on the Role of Private Sector in Social Waste Management of Pokhara Sub-Metropolis Area. MBA diss. 2056.

Suhang, Tek Prasad. Capital Structure of Unilever Nepal Limited, MBS diss. 2063

Tamang, Santa Bahadur. Working Capital Analysis of Listed Manufacturing Companies, MBS diss. 2063

Tej Prasad Basyal. A Study on Marketing of Mobile Telephone Service in Nepal (With Special Reference to Kathmandu Valley) MBA diss. 2057.

Thapa, Bhoj Bdr. A Case Study of Gandaki Noodle (Pvt) Ltd. MBA diss. 2055.

Thapa, Kiran Kumar. Risk and Return Analysis of Finance Companies of Nepal, MBS diss. 2063.

Thapa, Mohan Bdr. A Study on the Performance Evaluation of Finance Company: A Case Study of Apco. Ltd. MBA diss. 2058.

Thapa, Yam Maya. Behaviour of Nepal Stock Exchange Index, MBS diss. 2062.

Timsina, Baikuntha Raj. A Study on Motivational Aspect of Machhapuchhre Bank Ltd. MBA diss. 2058.

Tiwari, Deepak Raj. A Study on Inventory Management of Salt Trading Corporation Limited. MBS diss. 2061.

Yadav, Umesh Singh. A Comparative Study on Advertising Media Usage and Selection Practice of Manufacturing and Service Industry in Pokhara. MBA diss. 2059. 